\title{
Effects of alpha lipoic acid on ischemia-reperfusion injury in rat hindlimb ischemia model
}

\author{
Arif Aydın, M.D., ${ }^{1}$ Alpagan Mustafa Yıldırım, M.D. ${ }^{2}$ \\ ${ }^{1}$ Department of Plastic Reconstructive and Aesthetic Surgery, Afyonkarahisar State Hospital, Afyonkarahisar-Turkey \\ ${ }^{2}$ Department of Plastic Reconstructive and Aesthetic Surgery, Afyon Kocatepe University Faculty of Medicine, Afyonkarahisar-Turkey
}

\begin{abstract}
BACKGROUND: This study was performed to evaluate the effect of alpha lipoic acid (ALA) on prevention of ischemia-reperfusion (IR) injury in rat hindlimb ischemia model.

METHODS: Forty male Sprague Dawley rats weighing between 250 and $300 \mathrm{~g}$ were divided into 4 groups of 10 rats. Hindlimb composite island flaps were raised in all rats. Clamps were applied to femoral vessels of all subjects, but immediately released without causing ischemia in Group I. In Group 2, after 4 hours of ischemia, 24 hours of reperfusion was performed. Following 4 hours of ischemia, saline was administered to rats in Group 3 and flaps were reperfused for 24 hours. In Group 4, ALA was administered intraperitoneally after 4 hours of ischemia and flaps were reperfused for 24 hours.
\end{abstract}

RESULTS: In Group 4, there was a significant decrease of liver malondialdehyde compared to Group 2 and decrease of muscle tumor necrosis factor-alpha compared to Group 3. There was also increase in levels of glutathione in erythrocytes compared to Group 3 and increase of plasma vitamin $\mathrm{C}$ compared to all groups.

CONCLUSION: ALA was found to be effective in prevention of ischemia-reperfusion injury. Further studies are needed before clinical application.

Key words: Alpha lipoic acid; ischemia-reperfusion; rat.

\section{INTRODUCTION}

A flap is a unit of tissue that is transferred from the donor area to another site of the body with its blood supply preserved intact. Flaps are widely used in reconstructive surgery for defects caused by various conditions such as trauma, surgery, tumors, and congenital diseases. One of the major problems after flap transfer is partial or total necrosis. A great deal of research has been conducted on prevention of flap necrosis, and some studies have investigated prevention of ischemiareperfusion (IR) injury. Flap elevation causes ischemia, especially in distal part of the flap where vessels are removed. Flap circulation in first 24 hours determines flap survival.

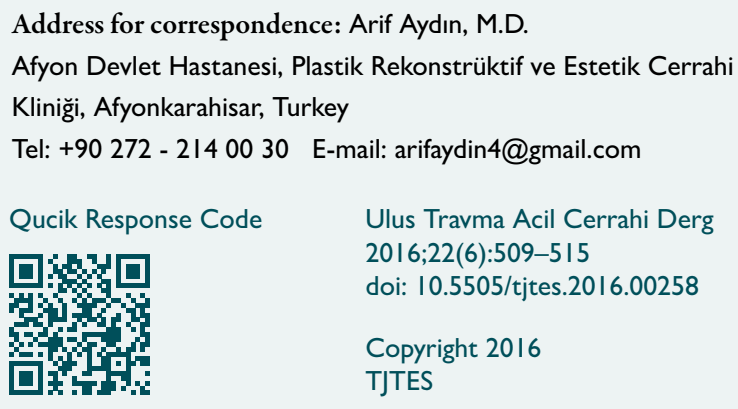

One of the primary causes of flap necrosis is IR injury arising from vascular endothelial damage. ${ }^{[1]}$ Ischemia damages cells through several mechanisms such as decreasing adenosine triphosphate and calcium, increasing carbon dioxide and lactic acid, and damaging cell membrane. Reperfusion causes cellular injury by creating free radicals, which induce neutrophil respiratory burst, neutrophil diapedesis, proinflammatory cytokines arising from leukocytes, thrombocytes, and endothelial cells. ${ }^{[2]}$

Alpha lipoic acid (ALA) is an endogen molecule that is essential for decarboxylation of pyruvate to acetyl coenzyme $A$ between glycolysis and Krebs cycle. ALA is an important cofactor of many mitochondrial enzyme complexes and a powerful antioxidant. It has been demonstrated that ALA and its reduced form, dihydrolipoic acid, neutralize reactive oxygen and reactive nitrogen species in vitro. ${ }^{[3]}$ In many studies, ALA has been reported to reduce IR injury in the myocardium, kidney, liver, ovaries, testes, peripheral nerves, and brain. ${ }^{[4-9]}$

The fundamental aim of this study was to investigate the effect of ALA on IR injury in rat hindlimb model. 


\section{MATERIALS AND METHODS}

This study was conducted with the permission of the ethics committee for animal experimentation of Afyon Kocatepe University. A total of 40 male Sprague Dawley rats with mean weight of 250 to $300 \mathrm{~g}$ were used in this study and were separated into 4 equal groups. Before and after the experiment, rats were fed with standard rat chow and water ad libitum, kept in a laboratory environment at 20 to $24^{\circ} \mathrm{C}$, and $12 / 12$ hour light/dark cycle was maintained.

After right hindlimb composite island flaps were raised, microvascular clamps (Acland Micro Vessel Clamp, Neuhausen, Switzerland) were applied to femoral artery and veins of all subjects.

Group I: Venous and then arterial clamps were immediately removed without creating ischemia.

Group 2: Clamps were left in place and after 4 hours of ischemia, first venous and then arterial clamps were removed and 24 hours of reperfusion was performed.

Group 3: After 4 hours of ischemia, venous clamp was removed, followed by arterial clamps. At initiation of 24 hours of reperfusion, $2 \mathrm{cc} / \mathrm{kg}$ of $0.09 \%$ saline was administered intraperitoneally.
Group 4: Following 4 hours of ischemia, first venous and then arterial clamps were removed. Intraperitoneal injection of 24 $\mathrm{mg} / \mathrm{kg}$ (2 cc/kg) of ALA (Thioctacid 600 T, Mylan N.V., Canonsburg, PA, USA/Meda Pharma GmbH \& Co., Bad Homburg vor der Höhe, Germany) was administered at start of 24hour period of reperfusion.

\section{Surgical Technique}

Rats were anesthetized with intramuscular injection of $100 \mathrm{mg} / \mathrm{kg}$ ketamine hydrochloride (Ketalar; Pfizer, Inc., NY, NY, USA) and $60 \mathrm{mg} / \mathrm{kg}$ xylazine (Rompun; Bayer AG, Leverkusen, Germany) combination. Animals were placed on operating table in supine position with limbs fastened to the table. Surgical site was shaved and wiped with $10 \%$ povidone iodine solution. Circular incision was made on right inguinal area, and femoral vessels were dissected and protected under $3 x$ loupe magnification (Fig. Ia, b). Muscles were incised circularly and osteotomy was performed on femur to prepare composite island flap (Fig. Ic). Microvascular clamps were placed on femoral vessels (Fig. Id). All the rats were anesthetized during 4 hours of ischemia, then awakened and observed for 24 hours before being euthanized (Fig. le, f). Tissue and blood samples were taken after sacrifice for analysis.
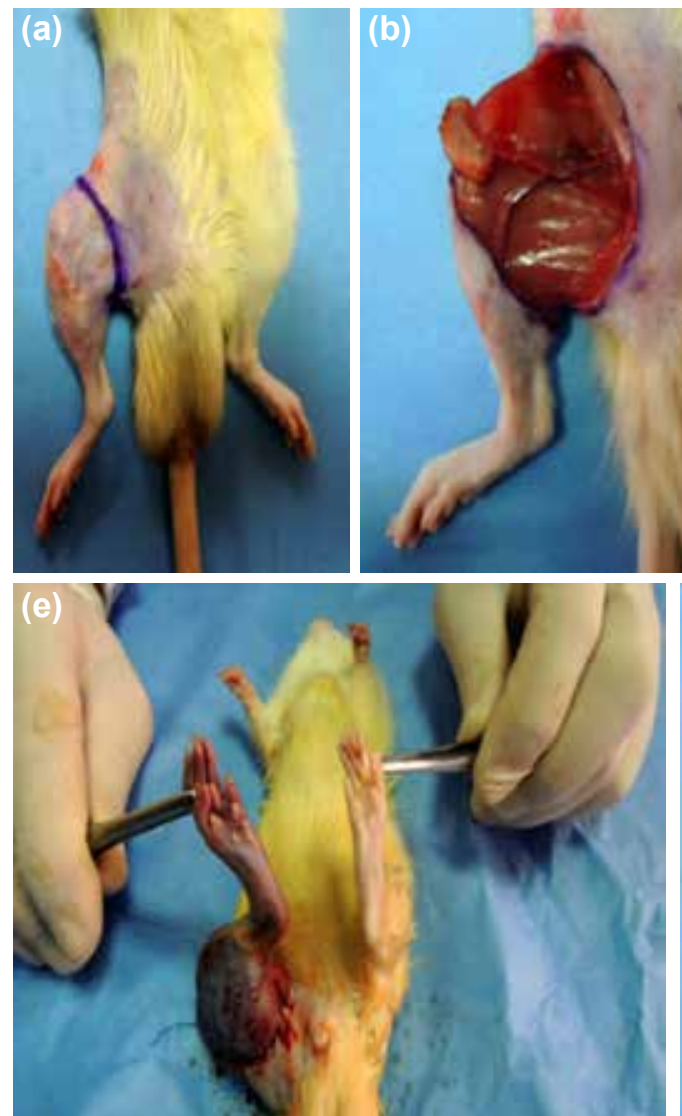
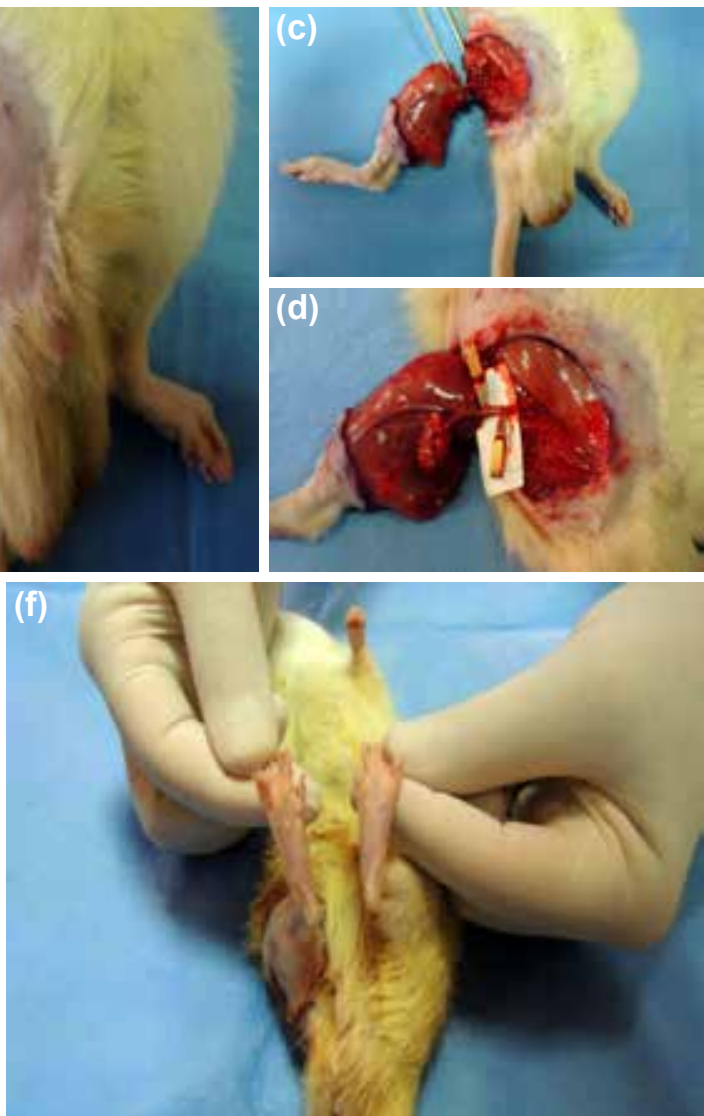

Figure 1. (a) Preoperative marking. (b) Dissection of femoral vessels. (c) Raising the hindlimb composite island flap after femur osteotomy. (d) Applying clamps to femoral artery and vein. (e) Macroscopic view after 4 hours of ischemia. (f) Macroscopic view after 24 hours of reperfusion. 


\section{Biochemical Evaluation}

Intracardiac blood samples, as well as gastrocnemius muscle and liver tissue samples were taken to analyze local tissue damage. Tissue samples were kept at $-20^{\circ} \mathrm{C}$ degrees. Malondialdehyde (MDA), tumor necrosis factor (TNF)-alpha, nitrite, and nitrate levels in plasma, muscle, and liver samples were tested using enzyme-linked immunosorbent assay (ELISA) technique. ELISA was also used to determine glutathione (GSH) levels in erythrocytes. Vitamin A, vitamin E, and vitamin $C$ levels in plasma were tested using high-performance liquid chromatography.

\section{Statistical Analysis}

SPSS software version 16.0 (SPSS Inc., Chicago, IL, USA) was used for statistical analyses of data obtained from the study. Shapiro-Wilk test was used to test assumption of normality. Normal values were evaluated with one-way analysis of variance test, and non-normal values were evaluated with Kruskal-Wallis test followed by Tukey's test. $P$ values of $<0.05$ were considered significant.

\section{RESULTS}

\section{Macroscopic Evaluation}

After 24 hours of follow up, 100\% survival of all the composite island flaps was observed.

\section{Biochemical Evaluation}

Significant increase was found in Group I compared to Group
2 and Group 3 in terms of plasma MDA ( $<<0.05)$. There was no significant difference between Groups 2, 3, and 4.

There was no significant difference between groups in muscle MDA levels ( $p>0.05)$, but values were lower in Group 4 compared to Group 2 and Group 3.

Liver MDA was significantly decreased in Group 4 compared to Group $2(p<0.05)$ (Table I).

Plasma TNF-alpha levels revealed no significant difference between groups $(p>0.05)$.

There was significant increase in Group 3 compared to Group I $(p<0.05)$ and Group $2(p<0.05)$ in terms of muscle TNF-alpha levels. There was significant decrease in Group 4 compared to Group 3 in terms of muscle TNF-alpha levels $(p<0.05)$.

Significant decrease was observed in Group 3 and Group 2 compared to Group I in liver TNF-alpha levels $(p<0.05)$. There was decrease in liver TNF-alpha levels in Group 4 compared to Group I, but statistically it was not significant (Table 2).

There was significant increase in plasma nitrate levels in Group 3 and Group 4 compared to Group I and Group 2 $(p<0.05)$. There was no significant difference between Group I and Group 2.

Muscle nitrate levels were significantly increased in Group 2,

Table I. Plasma, muscle, and liver MDA levels

\begin{tabular}{|c|c|c|c|}
\hline \multirow[t]{2}{*}{ Groups } & MDA plasma $(\mu \mathrm{M})$ & MDA muscle (mmol/g protein) & MDA liver (mmol/g protein) \\
\hline & Mean $\pm S D$ & Mean $\pm S D$ & Mean $\pm S D$ \\
\hline I & $6.00 \pm 3.61$ & $2.09 \pm 0.58$ & $0.88 \pm 0.09$ \\
\hline 2 & $1.99 \pm 1.25$ & $3.98 \pm 2.61$ & $1.14 \pm 0.33$ \\
\hline 3 & $2.77 \pm 2.53$ & $3.69 \pm 1.97$ & $0.96 \pm 0.27$ \\
\hline 4 & $3.74 \pm 2.5 \mathrm{I}$ & $2.44 \pm 1.53$ & $0.80 \pm 0.07$ \\
\hline
\end{tabular}

MDA: Malondialdehyde; SD: Standard deviation.

Table 2. Plasma, muscle, and liver tumor necrosis factor-alpha levels

\begin{tabular}{|c|c|c|c|}
\hline \multirow[t]{2}{*}{ Groups } & TNF plasma (pg/ml) & TNF muscle (ug/g protein) & TNF liver (ug/g protein) \\
\hline & Mean $\pm S D$ & Mean $\pm S D$ & Mean \pm SD \\
\hline I & $3.03 \pm 1.53$ & $95.90 \pm 56.59$ & $572 \pm 118$ \\
\hline 2 & $6.13 \pm 3.19$ & $92.90 \pm 75.22$ & $469 \pm 91$ \\
\hline 3 & $6.68 \pm 5.57$ & $250.30 \pm 163.32$ & $463 \pm 32$ \\
\hline 4 & $5.8 I \pm 4.37$ & $74.10 \pm 34.49$ & $502 \pm 60$ \\
\hline
\end{tabular}

TNF: Tumor necrosis factor; SD: Standard deviation. 
Group 3, and Group 4 compared to Group I ( $<<0.05)$. There was no significant difference between Groups 2, 3, and 4.

There was no significant difference between groups in terms of liver nitrate levels (Table 3).

There was no significant difference between groups in plasma nitrite levels.

No significant difference in muscle nitrite levels was determined between groups, but lower values were obtained in Group 4 compared to Groups I, 2, and 3.

There was no significant difference found in terms of liver nitrite levels (Table 4).

Levels of erythrocyte GSH in Group 4 were significantly in- creased compared to Group I $(p<0.05)$ and Group $3(p<0.05)$.

There was significant increase in Group I compared to Groups 2, 3, and 4 in terms of muscle GSH levels $(p<0.05)$. There was no significant difference between Groups 2, 3, and 4.

Significant decrease in liver GSH levels was seen in Group I compared to Groups 2, 3, and 4 ( $p<0.05)$. There was no significant difference between Groups 2, 3, and 4 (Table 5).

Group 4 had significant increase in plasma vitamin $C(p<0.05)$. There was no significant difference between other groups.

There was significant increase in Group I compared to others groups in plasma vitamin A levels $(p<0.05)$. There was no significant difference found between other groups.

Table 3. Plasma, muscle and liver nitrate levels

\begin{tabular}{|c|c|c|c|}
\hline \multirow[t]{2}{*}{ Groups } & \multirow{2}{*}{$\frac{\text { Nitrate plasma }(\mathrm{uM})}{\text { Mean } \pm \text { SD }}$} & \multirow{2}{*}{$\frac{\text { Nitrate muscle (mmol/g protein) }}{\text { Mean } \pm S D}$} & \multirow{2}{*}{$\frac{\text { Nitrate liver (mmol/g protein) }}{\text { Mean } \pm \text { SD }}$} \\
\hline & & & \\
\hline I & $11.92 \pm 4.44$ & $2.05 \pm 1.47$ & $0.55 \pm 0.12$ \\
\hline 2 & $20.03 \pm 11.89$ & $4.12 \pm 1.91$ & $0.55 \pm 0.12$ \\
\hline 3 & $39.64 \pm \mid 9.31$ & $3.93 \pm 2.71$ & $0.55 \pm 0.03$ \\
\hline 4 & $40.18 \pm 17.63$ & $5.38 \pm 3.71$ & $0.63 \pm 0.13$ \\
\hline
\end{tabular}

SD: Standard deviation.

Table 4. Plasma, muscle and liver nitrite levels

\begin{tabular}{|c|c|c|c|}
\hline \multirow[t]{2}{*}{ Groups } & \multirow{2}{*}{$\frac{\text { Nitrite plasma (uM) }}{\text { Mean } \pm \text { SD }}$} & \multirow{2}{*}{$\frac{\text { Nitrite muscle (mmol/g protein) }}{\text { Mean } \pm \text { SD }}$} & \multirow{2}{*}{$\frac{\text { Nitrite liver (mmol/g protein) }}{\text { Mean } \pm \text { SD }}$} \\
\hline & & & \\
\hline I & $3.38 \pm 1.08$ & $0.94 \pm 0.14$ & I. $15 \pm 0.33$ \\
\hline 2 & $2.32 \pm 1.04$ & I. $12 \pm 0.59$ & $1.01 \pm 0.12$ \\
\hline 3 & $2.04 \pm 1.60$ & $1.47 \pm 1.03$ & $0.94 \pm 0.08$ \\
\hline 4 & $3.16 \pm 1.28$ & $0.77 \pm 0.08$ & $1.13 \pm 0.29$ \\
\hline
\end{tabular}

SD: Standard deviation.

Table 5. Erythrocyte, muscle, and liver GSH levels

\begin{tabular}{lcccc}
\hline Groups & GSH erytrocyte (umol/g Hgb) & & GSH muscle (mmol/g protein) & $\frac{\text { GSH liver (mmol/g protein) }}{$\cline { 2 - 3 }} \\
\cline { 2 - 3 } & Mean \pm SD & & Mean \pm SD & Mean \pm SD \\
\hline 1 & $0.12 \pm 0.06$ & $0.35 \pm 0.24$ & $0.27 \pm 0.13$ \\
2 & $0.13 \pm 0.10$ & $0.12 \pm 0.04$ & $1.26 \pm 0.30$ \\
3 & $0.10 \pm 0.05$ & $0.16 \pm 0.10$ & $1.03 \pm 0.73$ \\
4 & $0.24 \pm 0.15$ & $0.10 \pm 0.03$ & $1.20 \pm 0.94$ \\
\hline
\end{tabular}

GSH: Glutathion; SD: Standard deviation. 
Table 6. Plasma vitamin C, vitamin A, vitamin E levels

\begin{tabular}{|c|c|c|c|}
\hline \multirow[t]{2}{*}{ Groups } & \multirow{2}{*}{$\frac{\text { Vitamin C }(\mathrm{mmol} / \mathrm{l})}{\text { Mean } \pm \text { SD }}$} & \multirow{2}{*}{$\frac{\text { Vitamin A }(\mathrm{mmol} / \mathrm{L})}{\text { Mean } \pm \text { SD }}$} & \multirow{2}{*}{$\frac{\text { Vitamin E }(\mathrm{mmol} / \mathrm{L})}{\text { Mean } \pm S D}$} \\
\hline & & & \\
\hline I & $0.57 \pm 0.35$ & $0.5 \mathrm{I} \pm 0.1 \mathrm{I}$ & $7.25 \pm 1.72$ \\
\hline 2 & $0.65 \pm 0.18$ & $0.30 \pm 0.07$ & $11.64 \pm 2.29$ \\
\hline 3 & $0.65 \pm 0.18$ & $0.27 \pm 0.05$ & $9.67 \pm 1.20$ \\
\hline 4 & $2.5 I \pm 2.80$ & $0.22 \pm 0.03$ & $7.22 \pm 1.69$ \\
\hline
\end{tabular}

SD: Standard deviation.

Plasma vitamin E levels increased significantly in Group 2 compared to Group I and Group $4(p<0.05)$. There was significant increase in Group 3 compared to Group I and Group 4 in terms of plasma vitamin $E(p<0.05)$. No significant difference was observed between Group 2 and Group 3 (Table 6).

\section{DISCUSSION}

Flap loss is still an important problem in reconstructive surgery. Although flap anatomy and physiology are better known as result of recent research, flap loss of $25 \%$ in pedicled skinmuscle flaps has been reported, though most are partial. ${ }^{[10]}$ Development of microsurgery made application of free flaps more common and flap survival rates increased, but new problems also occurred. Flap loss is less common in free flaps compared with pedicled flaps, but flap loss is usually total rather than partial. Independent of partial or total status, flap loss increases morbidity, mortality, hospitalization period, and number of surgeries performed.

IR injury is a big problem in major replantations and composite tissue allotransplantations, which is why rat hindlimb transplantation model was selected for the present study. ALA was tested to determine if it would reduce production of free oxygen radicals. Damage occurring during reperfusion from free radicals was demonstrated by measuring TNF-alpha, a cytokine that triggers inflammation, and GSH, which is an antioxidant substance. Lipid peroxidation, which causes cell membrane damage was assessed by measuring MDA. Nitric oxide (NO), which is a highly reactive free radical, is not stable, and when it reacts with oxygen, various nitric oxide products are formed. The most stable derivatives are nitrite and nitrate. Nitrite and nitrate levels were tested in the present study to estimate NO levels. In addition, plasma levels of vitamin A, E, and $C$ were measured to illustrate effect of ALA.

Unal et al. ${ }^{[I]}$ reported that gradually increased blood flow decreased IR injury. In our study, after 4 hours of ischemia, we first released venous clamp and then arterial with intent of returning normal blood flow to the extremity gradually.

Zaccaria et al. ${ }^{[12]}$ found that vitamin $C$ reduced IR injury. In the current study, plasma vitamin $C$ levels were significantly increased in rats that received intraperitoneal ALA compared with all other groups. We think that ALA contributes antioxidant effect by increasing vitamin $C$.

It was suggested that ALA had protective effect in a model where peroxy radical was used to induce erythrocyte hemolysis. ${ }^{[13]}$ Also, it was found that ALA stabilized erythrocyte membrane and increased myocardial blood flow in an IR model using myocardial cells. ${ }^{[14]}$ Yilmaz et al. reported that ALA, ascorbic acid-6-palmitate, and fish oil improve recycling of glutathione disulfide into reduced GSH in erythrocytes of diabetic rats. ${ }^{[15]}$ In our study, significant increase in erythrocyte GSH levels was found in rats that had ALA administered compared with rats that received saline injection and rats that did not undergo ischemia reperfusion. It is possible that ALA protects erythrocyte membrane by increasing levels of GSH.

Yamada et al. ${ }^{[16]}$ reported that in hepatocytes stimulated with proinflammatory cytokines, ALA suppressed iNOS gene expression and prevented excess $\mathrm{NO}$ expression. However, in present study no significant decrease in levels of nitrite or nitrate was found in plasma, muscle, or liver in the ALA group compared with other groups. Tunc et al. ${ }^{[17]}$ studied intestinal IR model in which clamp was applied to superior mesenteric artery for 30 minutes followed by 3 days of reperfusion. Superoxide dismutase, MDA, protein carbonyl, and glutathione peroxidase levels were measured in intestine tissue. They reported that MDA levels were significantly lower in rats treated with ALA in comparison with IR group. In addition, glutathione peroxidase levels were significantly higher in rats treated with ALA in comparison with IR group, but lower than control group. In present study, erythrocyte GSH levels were even higher in ALA treatment group than control group; however, we didn't find any beneficial effect of ALA in terms of muscle and liver GSH. Koga et al. ${ }^{\left[{ }^{[8]}\right.}$ conducted IR study on kidneys and found decreased levels of blood urea nitrogen, creatinine, and MDA in ALA treatment group compared to control group. In our study, we found significantly decreased levels of liver MDA in ALA treatment group compared with IR group. On the other hand, we didn't find any beneficial effects of ALA in plasma in terms of MDA. 
Huk-Kolega et al. ${ }^{[19]}$ found that ALA significantly decreased TNF-alpha level in rat spleen homogenates. In current study, muscle TNF-alpha levels were significantly decreased in ALA treatment group compared with rats that had saline administered. Safa et al. ${ }^{[20]}$ investigated effects of ALA supplementation on serum levels of interleukin-8 and TNF-alpha in patients with end-stage renal disease undergoing hemodialysis. There was no significant difference between treatment group and placebo group. There was also no significant difference between groups in our study in terms of plasma TNF-alpha levels. Furthermore, we did not find any beneficial effects of ALA with respect to liver TNF-alpha.

Werker et al. ${ }^{[2]}$ investigated effects of ALA and desferrioxamine on cold ischemia tolerance in rat epigastric free flap model. After elevating epigastric flaps, they administered I5 $\mathrm{mg} / \mathrm{kg}$ ALA and applied clamp to pedicle. Flaps were perfused with $0^{\circ} \mathrm{C}$ hypertonic citrate solution for 4 intervals: $0,72,96$, and 120 hours. Before releasing clamps, $15 \mathrm{mg} /$ kg ALA was administered once again. Same procedure was followed with desferrioxamine. In comparison with control group, they found that neither desferrioxamine nor ALA enhanced cold ischemic tolerance of epigastric free flaps in rats. In present study, composite flap model was used, 4 hours warm ischemia was applied, and higher dose of ALA $(24 \mathrm{mg} / \mathrm{kg})$ was administered.

Freisleben et al. ${ }^{[22]}$ disarticulated both hindlimbs of rats, used right hindlimb as control group $(n=7)$ and left hindlimb as treatment group $(n=8)$. They cannulated femoral artery and vein, and after 4 hours of ischemia at $18^{\circ} \mathrm{C}$ degrees, reperfusion was carried out for 30 minutes with a controlled reperfusate, followed by 30 minutes modified Krebs-Henseleit solution. In the treatment group, they added $8.33 \mathrm{mM}$ dihydrolipoic acid to the controlled reperfusion solution. They evaluated muscle contraction, flexibility of the hindlimbs, and creatine kinase in the buffer after 15 minutes of reperfusion. In the treatment group, they found muscle contractile function was significantly higher and creatine kinase levels were significantly lower, compared to control group. In our study, reperfusion was established with blood flow, which is more physiological. To evaluate reperfusion damage, we measured parameters that are more specific to IR injury and used separate rats for each group to obtain more objective results.

The present study is unique in showing the effects of ALA on IR injury in composite island flaps. Further studies are needed using different types of flap models and more parameters to determine efficacy of ALA. ALA is cheap, easy to apply, and doesn't require special equipment. It doesn't have risks of infection, bleeding, or pain. It is our belief that ALA may be applied in clinics in order to prevent IR injury in the future.

Conflict of interest: None declared.

\section{REFERENCES}

1. Leng X, Zhang Q, Zhai X, Chen Z. Local transplant of human umbilical cord matrix stem cells improves skin flap survival in a mouse model. Tohoku J Exp Med 2012;227:191-7. Crossref

2. Gute DC, Ishida T, Yarimizu K, Korthuis RJ. Inflammatory responses to ischemia and reperfusion in skeletal muscle. Mol Cell Biochem 1998;179:169-87. Crossref

3. Kramer K, Packer L. R-alpha-lipoic acid. In: Kramer K, Hoppe P, Packer L, editors. Nutraceuticals in Health and Disease Prevention. New York: Marcel Dekker, Inc. 2001. p. 129-64.

4. Sehirli O, Sener E, Cetinel S, Yüksel M, Gedik N, Sener G. Alpha-lipoic acid protects against renal ischaemia-reperfusion injury in rats. Clin Exp Pharmacol Physiol 2008;35:249-55. Crossref

5. Takaoka M, Ohkita M, Kobayashi Y, Yuba M, Matsumura Y. Protective effect of alpha-lipoic acid against ischaemic acute renal failure in rats. Clin Exp Pharmacol Physiol 2002;29:189-94. Crossref

6. Cosar E, Sahin FK, Köken G, Toy H, Basarali K, Büyükbas S. The protective effect of alpha-lipoic acid in experimental ovarian ischaemia-reperfusion injury. Aust N Z J Obstet Gynaecol 2007;47:499-503. Crossref

7. Müller C, Dünschede F, Koch E, Vollmar AM, Kiemer AK. Alpha-lipoic acid preconditioning reduces ischemia-reperfusion injury of the rat liver via the PI3-kinase/Akt pathway. Am J Physiol Gastrointest Liver Physiol 2003;285:G769-78. Crossref

8. Xie R, Li X, Ling Y, Shen C, Wu X, Xu W, et al. Alpha-lipoic acid preand post-treatments provide protection against in vitro ischemia-reperfusion injury in cerebral endothelial cells via Akt/mTOR signaling. Brain Res 2012;1482:81-90. Crossref

9. Wang X, Yu Y, Ji L, Liang X, Zhang T, Hai CX. Alpha-lipoic acid protects against myocardial ischemia/reperfusion injury via multiple target effects. Food Chem Toxicol 2011;49:2750-7. Crossref

10. Dunn RM, Mancoll J. Flap models in the rat: a review and reappraisal. Plast Reconstr Surg 1992;90:319-28. Crossref

11. Unal S, Ozmen S, DemIr Y, Yavuzer R, LatIfoğlu O, Atabay K, et al. The effect of gradually increased blood flow on ischemia-reperfusion injury. Ann Plast Surg 2001;47:412-6. Crossref

12. Zaccaria A, Weinzweig N, Yoshitake M, Matsuda T, Cohen M. Vitamin $\mathrm{C}$ reduces ischemia-reperfusion injury in a rat epigastric island skin flap model. Ann Plast Surg 1994;33:620-3. Crossref

13. Constantinescu A, Tritschler H, Packer L. alpha-Lipoic acid protects against hemolysis of human erythrocytes induced by peroxyl radicals. Biochem Mol Biol Int 1994;33:669-79.

14. Ghibu S, Lauzier B, Delemasure S, Amoureux S, Sicard P, Vergely C, et al. Antioxidant properties of alpha-lipoic acid: effects on red blood membrane permeability and adaptation of isolated rat heart to reversible ischemia. Mol Cell Biochem 2009;320:141-8. Crossref

15. Yilmaz O, Ozkan Y, Yildirim M, Oztürk AI, Erşan Y. Effects of alpha lipoic acid, ascorbic acid-6-palmitate, and fish oil on the glutathione, malonaldehyde, and fatty acids levels in erythrocytes of streptozotocin induced diabetic male rats. J Cell Biochem 2002;86:530-9. Crossref

16. Yamada M, Kaibori M, Tanaka H, Habara K, Hijikawa T, Tanaka Y, et al. alpha-lipoic acid prevents the induction of iNOS gene expression through destabilization of its mRNA in proinflammatory cytokine-stimulated hepatocytes. Dig Dis Sci 2012;57(4):943-51. Crossref

17. Tunc T, Oter S, Güven A, Topal T, Kul M, Korkmaz A, et al. Protective effect of sulfhydryl-containing antioxidants against ischemia/reperfusion injury of prepubertal rat intestine. J Gastroenterol Hepatol 2009;24(4):681-7. Crossref

18. Koga H, Hagiwara S, Kusaka J, Goto K, Uchino T, Shingu C, et al. New $\alpha$-lipoic acid derivative, DHL-His $\mathrm{Zn}$, ameliorates renal ischemia-reperfusion injury in rats. J Surg Res 2012;174:352-8. Crossref

19. Huk-Kolega H, Ciejka E, Skibska B, Kowalczyk A, Goraca A. Influence of lipoic acid on the level of TNF-alpha in spleen homogenates. [Article 
in Polish] Pol Merkur Lekarski 2014;36:379-81. [Abstract]

20. Safa J, Ardalan MR, Rezazadehsaatlou M, Mesgari M, Mahdavi R, Jadid MP. Effects of alpha lipoic acid supplementation on serum levels of IL-8 and TNF- $\alpha$ in patient with ESRD undergoing hemodialysis. Int Urol Nephrol 2014;46:1633-8. Crossref
21. Werker PM, Kon M, Green CJ, Franken RJ, Overgoor ML. Neither desferrioxamine nor lipoic acid enhances the cold ischaemic tolerance of epigastric free flaps in rats. Microsurgery 1993;14:574-8. Crossref

22. Freisleben HJ. Lipoic acid reduces ischemia-reperfusion injury in animal models. Toxicology 2000;148:159-71. Crossref

\section{DENEYSEL ÇALIŞMA - ÖZET}

\section{Sıçanlarda arka bacak iskemi modelinde alfa lipoik asitin iskemi/ reperfüzyon hasarı üzerine etkisi \\ Dr. Arif Aydın, ${ }^{1}$ Dr. Alpagan Mustafa Yıldırım²}

${ }^{1}$ Afyonkarahisar Devlet Hastanesi, Plastik Rekonstrüktif ve Estetik Cerrahi Kliniği, Afyonkarahisar ${ }^{2}$ Afyon Kocatepe Üniversitesi Tıp Fakültesi, Plastik Rekonstrüktif ve Estetik Cerrahi Anabilim Dalı, Afyonkarahisar

AMAÇ: Bu çalışma sıçanlarda arka bacak modelinde alfa lipoik asitin iskemi reperfüzyon hasarını önlemedeki etkinliğini araştırmak amacıyla yapıldı. GEREÇ VE YÖNTEM: Çalışmada 250-300 gr ağırlığında 40 adet Sprague Dawley cinsi erkek sıçan kullanıldı. Her grupta 10 hayvan olacak şekilde, randomize dört grup oluşturuldu. Tüm sıçanlarda arka bacak kompozit ada flebi hazırlandı. Grup I'de arka bacakta femoral damarlara klemp uygulanıp hemen açıldı ve iskemi oluşturulmadı. Grup 2'de dört saat iskemi uygulandı ve sonrasında 24 saat reperfüzyon edildi. Grup 3'te dört saat iskemi sonrası parenteral olarak serum fizyolojik verildi ve 24 saat reperfüzyon yapıldı. Grup 4'te dört saatlik iskemi sonrası parenteral olarak alfa lipoik asit verildi ve 24 saat reperfüzyon yapıldı. Tüm sıçanlar 24 saatlik reperfüzyon sonrası sakrifiye edildi. Biyokimyasal inceleme için kan, karaciğer ve transplante edilen arka bacaktan kas dokusu örneği alındı. Homogenizasyon sonrası kanda ve dokularda nitrit, nitrat, glutatyon, MDA, TNF-alfa, plazmada vitamin $A$, vitamin $E$, vitamin $C$ düzeyleri test edildi.

BULGULAR: İskemi sonrası alfa lipoik asit eklenen grupta GSH (eritrosit), MDA (karaciğer), vitamin C (plazma),TNF-alfa (kas) değerlerinde yalnız iskemi veya iskemi ve serum fizyolojik uygulanan gruplara göre anlamlı farklar görüldü.

TARTIŞMA: Çalışmamızda, alfa lipoik asitin iskemi-reperfüzyon hasarını önlemede olumlu etkilerinin olduğu bulunmuştur. Ancak klinik uygulama için yeni ve geniş çalışmalara intiyaç vardır.

Anahtar sözcükler: Alfa lipoik asit; iskemi-reperfüzyon; sıçan.

Ulus Travma Acil Cerrahi Derg 2016;22(6):509-5I5 doi: 10.5505/tjtes.2016.00258 